\title{
Summertime tropospheric ozone assessment over the Mediterranean region using the thermal infrared IASI/MetOp sounder and the WRF-Chem model
}

\author{
S. Safieddine ${ }^{1}$, A. Boynard ${ }^{1}$, P.-F. Coheur ${ }^{2}$, D. Hurtmans ${ }^{2}$, G. Pfister ${ }^{3}$, B. Quennehen ${ }^{1}$, J. L. Thomas ${ }^{1}$, J.-C. Raut ${ }^{1}$, \\ K. S. Law ${ }^{1}$, Z. Klimont ${ }^{4}$, J. Hadji-Lazaro ${ }^{1}$, M. George ${ }^{1}$, and C. Clerbaux ${ }^{1,2}$ \\ ${ }^{1}$ Sorbonne Universités, UPMC Univ. Paris 06; Université Versailles St-Quentin; CNRS/INSU, LATMOS-IPSL, Paris, France \\ ${ }^{2}$ Spectroscopie de l'Atmosphère, Chimie Quantique et Photophysique, Université Libre de Bruxelles (U.L.B.), \\ Brussels, Belgium \\ ${ }^{3}$ Atmospheric Chemistry Division, National Center for Atmospheric Research, Boulder, Colorado, USA \\ ${ }^{4}$ International Institute for Applied Systems Analysis, Laxenburg 2361, Austria
}

Correspondence to: S. Safieddine (sarah.safieddine@latmos.ipsl.fr)

Received: 7 March 2014 - Published in Atmos. Chem. Phys. Discuss.: 14 May 2014

Revised: 7 August 2014 - Accepted: 23 August 2014 - Published: 23 September 2014

\begin{abstract}
Over the Mediterranean region, elevated tropospheric ozone $\left(\mathrm{O}_{3}\right)$ values are recorded, especially in summer. We use the thermal Infrared Atmospheric Sounding Interferometer (IASI) and the Weather Research and Forecasting Model with Chemistry (WRF-Chem) to understand and interpret the factors and emission sources responsible for the high $\mathrm{O}_{3}$ concentrations observed in the Mediterranean troposphere. Six years (2008-2013) of IASI data have been analyzed and results show consistent maxima during summer, with an increase of up to $22 \%$ in the $[0-8] \mathrm{km} \mathrm{O}_{3}$ column in the eastern part of the basin compared to the middle of the basin. We focus on summer 2010 to investigate the processes that contribute to these summer maxima. Using two modeled $\mathrm{O}_{3}$ tracers (inflow to the model domain and local anthropogenic emissions), we show that, between the surface and $2 \mathrm{~km}, \mathrm{O}_{3}$ is mostly formed from anthropogenic emissions, while above $4 \mathrm{~km}$ it is mostly transported from outside the domain or from stratospheric origins. Evidence of stratosphere-to-troposphere exchange (STE) events in the eastern part of the basin is shown, and corresponds to a low water vapor mixing ratio and high potential vorticity.
\end{abstract}

\section{Introduction}

Tropospheric ozone $\left(\mathrm{O}_{3}\right)$ is a greenhouse gas, air pollutant, and a primary source of the hydroxyl radical $(\mathrm{OH})$, the most important oxidant in the atmosphere (Chameides and Walker, 1973; Crutzen, 1973). Previous observations and studies have shown that tropospheric $\mathrm{O}_{3}$ over the Mediterranean exhibits a significant increase during summertime, especially in the east of the basin (Kouvarakis et al., 2000; Im et al., 2011; Gerasopoulos et al., 2005, 2006a; Richards et al., 2013; Zanis et al., 2014). Meteorological conditions such as frequent clear-sky conditions (Fig. 1a) and high exposure to solar radiation (Fig. 1b) in summer enhance the formation of photochemical $\mathrm{O}_{3}$ due to the availability of its precursors. These precursors include carbon monoxide (CO), peroxyl radicals generated by the photochemical oxidation of volatile organic compounds (VOCs) and nitrogen oxides $\left(\mathrm{NO}_{\mathrm{x}}=\mathrm{NO}+\mathrm{NO}_{2}\right)$. Locally, the eastern part of the basin is surrounded by megacities such as Cairo, Istanbul, and Athens that are large sources of local anthropogenic emissions. The geographic location of the basin makes it a receptor for anthropogenic pollution from Europe both in the boundary layer (Fig. 1c) and the mid-troposphere (Fig. 1d). The threshold $\mathrm{O}_{3}$ value for air quality standards for the European Union (of daily maximum of running $8 \mathrm{~h}$ mean values of $60 \mathrm{ppbv}$ ) is exceeded on more than 25 days per year at a large number of stations across Europe, many of which are 
located to the south of Europe in the Mediterranean Basin (EEA, 2012). The dynamical processes of the summer circulation over the Mediterranean were previously attributed to the Hadley cell considered as the driver of the major subtropical dry zones. Rodwell and Hoskins (1996) argued that, during the June-August period, the zonal mean Hadley circulation has very little motion and cannot explain the dry season of North Africa and the Mediterranean. Rodwell and Hoskins (1996, 2001) suggested, through numerical simulations, that the Asian monsoon heating induces an equatorially trapped Rossby wave to its west that interacts with the midlatitude westerlies, producing a region of adiabatic descent and triggering subsidence. Long-term analysis of $\mathrm{d} P / \mathrm{d} t$ (unit: $\mathrm{Pa} \mathrm{s}^{-1}$, used to represent subsidence) indeed shows a positive enhancement over the Mediterranean region (Ziv et al., 2004), making the South Asian monsoon a fundamental driver of the summer circulation over the eastern Mediterranean (Tyrlis et al., 2013). High $\mathrm{O}_{3}$ values in the Mediterranean troposphere in the literature are attributed to different sources. Lelieveld et al. (2002) showed that, in the upper troposphere, Asian pollution is transported from the east by the monsoon across the Mediterranean tropopause into the lower stratosphere. Liu et al. (2011) showed with longterm model analysis that the dominant sources of $\mathrm{O}_{3}$ in the Middle East (including the Mediterranean) are the transport from Asia and local production. On the other hand, Gerasopoulos et al. (2005) have shown that the mechanism that controls surface $\mathrm{O}_{3}$ seasonal variability in the eastern basin during summer is mainly the transport from Europe. Using lidar measurements, Galani et al. (2003) detected an increase of $10 \%$ of tropospheric $\mathrm{O}_{3}$ between 4.5 and $6.5 \mathrm{~km}$ due to stratosphere-to-troposphere exchange (STE) events. Zbinden et al. (2013), using aircraft data from the MOZAIC (Measurements of OZone and water vapour by in-service AIrbus airCraft) program over 15 years (1994-2009), showed that the tropospheric $\mathrm{O}_{3}$ columns in the east of the Mediterranean reached a maximum of $43.2 \mathrm{DU}$ (Dobson units) during June-July. This recorded maximum exceeds the maximum recorded for Beijing for the same period, for example. Model calculation using WRF-Chem (Weather Research and Forecasting model coupled with Chemistry) and EMEP (European Monitoring and Evaluation Programme) MSC-W (Meteorological Synthesizing Centre - West) models of the eastern Mediterranean during heat waves in 2007 showed that the daily maximum near-surface $\mathrm{O}_{3}$ is mostly sensitive to anthropogenic emissions of $\mathrm{O}_{3}$ precursors (Hodnebrog et al., 2012). Im et al. (2011) found that the near-surface ozone mixing ratios increase almost linearly with temperature by $1.0 \pm 0.1 \mathrm{ppb} \mathrm{O}_{3}$ per kelvin. STE processes can affect the tropospheric $\mathrm{O}_{3}$ budget and impact air quality if transported to the boundary layer (Fiore et al., 2002). Stratospheric intrusions have been detected in the Mediterranean region, especially on the eastern side (Galani et al., 2003; Zanis et al., 2014), because it lies to the south of the Northern Hemisphere polar jet flowing over midlatitudes (Stohl et al., 2000;
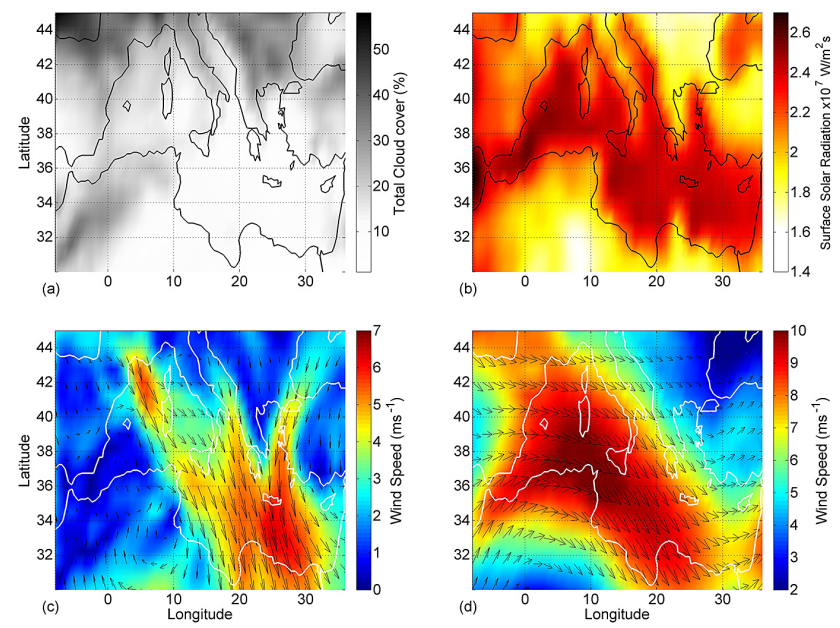

Figure 1. An example of the ECMWF (European Centre for Medium-Range Weather Forecasts) Reanalysis (ERA-Interim) for the period June-July-August (JJA) 2010 for (a) total cloud coverage, (b) 12:00 UTC solar radiation reaching the surface, (c) wind speed and direction averaged from the surface to $750 \mathrm{hPa}$, and (d) wind speed and direction averaged from 750 to $400 \mathrm{hPa}$.

Gerasopoulos et al., 2001). Understanding the factors that contribute to the $\mathrm{O}_{3}$ maxima is important for developing control measures and preventing pollution buildup. In this study we analyze $\mathrm{O}_{3}$ and its sources at different altitudes in the Mediterranean troposphere. Section 2 introduces the model and observations data sets used in this study. In Sect. 3, we analyze 6 years (2008-2013) of Infrared Atmospheric Sounding Interferometer (IASI) tropospheric $[0-8] \mathrm{km} \mathrm{O}$ column seasonal variation above the whole Mediterranean Basin as well as at 15 and $30^{\circ} \mathrm{E}$, representative of what we henceforth refer to as "middle of the basin" and "east of the basin" respectively. In Sect. 4 we focus on summer 2010, as an example year, and validate the WRF-Chem model simulation with surface $\mathrm{O}_{3}$ and IASI data, and then use the WRFChem model to assess the sources of $\mathrm{O}_{3}$ in the troposphere. In Sect. 5, we use IASI and WRF-Chem free-tropospheric $\mathrm{O}_{3}$ data to investigate potential STE events. Discussion and conclusions are given in Sect. 6.

\section{Model and observational data}

\subsection{WRF-Chem model}

In this study, we use the regional chemistry transport model WRF-Chem, version 3.2 (Grell et al., 2005), to assess the budget and spatiotemporal variability of $\mathrm{O}_{3}$ over the Mediterranean during summer 2010. The model domain shown in Fig. 2a is over Europe and the Mediterranean Basin, the latter being the focus of this study (Fig. 2b). The horizontal resolution is of $50 \mathrm{~km} \times 50 \mathrm{~km}$ and the vertical resolution is of 28 levels between the surface and $10 \mathrm{hPa}$. The 


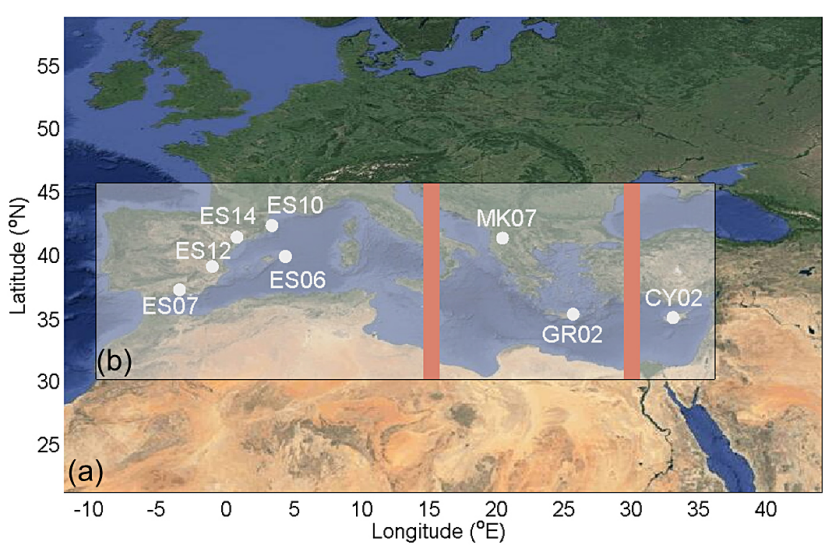

Figure 2. (a) The enlarged WRF-Chem model run domain. (b) IASI and WRF-Chem domain used in this study. White dots correspond to the location of the EMEP ground stations and the orange strips correspond to the longitudinal transects used in Figs. 5 and 10.

meteorological initial and boundary conditions are based on the National Centers for Environmental Prediction (NCEP) Final (FNL) analyses with analysis nudging for wind, temperature, and humidity applied. Fields are provided every $6 \mathrm{~h}$ with $1^{\circ}$ horizontal resolution and 27 vertical levels from the surface up to $10 \mathrm{hPa}$. The chemical initial and boundary conditions, spatially and temporally varying $(6 \mathrm{~h})$, are constrained by global chemical transport simulations from MOZART-4/GEOS-5 with $1.9^{\circ} \times 2.5^{\circ}$ horizontal resolution (Emmons et al., 2010a). The WRF-Chem gas-phase chemical mechanism is that from Model for Ozone and Related Chemical Tracers, version 4 (MOZART-4) (Emmons et al., 2010a), which is coupled to the aerosol scheme Goddard Chemistry Aerosol Radiation and Transport (GOCART) model (Chin et al., 2002). The model also includes anthropogenic and fire emissions that are calculated offline. The anthropogenic emissions used within the WRF-Chem model were developed within the context of the ECLIPSE European project using the Greenhouse gas and Air pollution Interactions and Synergies (GAINS) model. In addition to the ECLIPSE V4.0 anthropogenic emissions, ship emissions from the RCP 6.0 scenario (Fujino et al., 2006; Hijioka et al., 2008) were used. Biomass burning emissions are obtained from the Fire Inventory from NCAR (FINN V1) (Wiedinmyer et al., 2011). Biogenic emissions are calculated online from the Model of Emissions of Gases and Aerosols from Nature (MEGAN) (Guenther et al., 2006). The WRF-Chem simulation outputs are saved every $2 \mathrm{~h}$ from 1 June until 31 August 2010.

In this study, we use a tagging method for $\mathrm{O}_{3}$ (Emmons et al., 2012), which has been applied in global models for diagnosing contributions for individual sources to $\mathrm{O}_{3}$ (e.g., Lamarque et al., 2005; Pfister et al., 2006, 2008; Emmons et al., 2010b; Wespes et al., 2012), as well as in other global and regional chemical transport models (Ma et al., 2002; Hess and Zbinden, 2013). Recently, this scheme was used for the first time in the WRF-Chem model to quantify the contribution of transport on surface $\mathrm{O}_{3}$ over California (Pfister et al., 2013). Here, we apply this scheme to keep track of the contribution of $\mathrm{O}_{3}$ within the WRF-Chem domain. To determine $\mathrm{O}_{3}$ sources, tagged $\mathrm{NO}_{\mathrm{x}}$ is traced through the odd nitrogen species (e.g., PAN, $\mathrm{HNO}_{3}$, organic nitrates) to account for $\mathrm{NO}_{\mathrm{x}}$ recycling (Emmons et al., 2012). Two separate tracer runs were conducted with the same emissions and initial and boundary conditions. In the first one, the $\mathrm{O}_{3 \text {-ANTHRO }}$ tracer accounts for the anthropogenic regional tagged $\mathrm{NO}_{\mathrm{x}}$, while the second one, the $\mathrm{O}_{3 \text {-INFLOW tracer, accounts for }}$ tagged $\mathrm{O}_{3}$ as well as all nitrogen species at the lateral boundaries of the regional model domain. The $\mathrm{O}_{3 \text {-INFLOw tracer }}$ includes $\mathrm{O}_{3}$ and $\mathrm{O}_{3}$ precursors from all natural (including lightning and stratospheric $\mathrm{O}_{3}$ ) and anthropogenic sources outside the regional modeling domain. Within the regional modeling domain, $\mathrm{O}_{3-\mathrm{INFLOW}}$ undergoes transport and chemical processes but is not produced from sources other than from reactions including the tagged species. Since the stratospheric $\mathrm{O}_{3}$ is controlled by the lateral boundaries in this version of WRF-Chem, $\mathrm{O}_{3}$ from stratospheric intrusions within the regional domain would be labeled as $\mathrm{O}_{3 \text {-INFLOw }}$ as well. More details about the tagging scheme are provided in Emmons et al. (2012). Two more tracers are available to complete the $\mathrm{O}_{3}$ budget: $\mathrm{O}_{3}$ from biogenic sources and $\mathrm{O}_{3}$ from fires. Given that their contribution to the total budget in com-

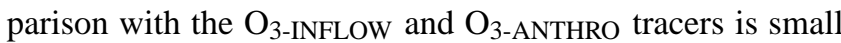
$(<10 \%)$, they are analyzed together in this study as "residuals" to the total budget and their contribution is defined as $100 \%-\left(\mathrm{O}_{3 \text {-ANTHRO }} \%+\mathrm{O}_{3 \text {-INFLOW }} \%\right)$. We focus our analysis on summer 2010, which corresponds to the year of the anthropogenic emission inventory used in the model. During July-August 2010, a heat wave occurred in Russia that caused severe fires with high $\mathrm{O}_{3}$ and $\mathrm{O}_{3}$ precursor emissions that were probably transported to the Mediterranean region; this will be further investigated in this study.

\subsection{EMEP data}

The EMEP (European Monitoring and Evaluation Programme) $\mathrm{O}_{3}$ hourly data (http://ebas.nilu.no/) are used to validate the WRF-Chem model at the surface. All ozone measurements within EMEP are done with UV monitors. In this study, measurements at eight ground rural background sites during the summer of 2010 are used. Details on the EMEP observation system can be found in Hjellbrekke et al. (2012). The geographic locations of the eight stations used for validation are plotted in Fig. 2, and the corresponding details are listed in Table 1. Two more station data sets were available, GR01-Aliartos $\left(38.37^{\circ} \mathrm{N}, 23.11^{\circ} \mathrm{E}\right)$ and IT01-Montelibretti $\left(42.1^{\circ} \mathrm{N}, 12.63^{\circ} \mathrm{E}\right)$, for the same period. We disregarded the data from these stations because they show a strong diurnal variation of $80-90 \mathrm{ppbv}$ amplitude and recurrent near-zero $\mathrm{O}_{3}$ concentrations throughout the period of the study, and were thus considered unreliable. 
Table 1. List of geographic location of the EMEP $\mathrm{O}_{3}$ monitoring ground stations used in this study, with the corresponding altitude above mean sea level.

\begin{tabular}{llrrr}
\hline Code & Station name & Latitude $\left({ }^{\circ} \mathrm{N}\right)$ & Longitude $\left({ }^{\circ} \mathrm{E}\right)$ & Altitude $(\mathrm{m})$ \\
\hline CY02 & Ayia Marina & 35.04 & 33.06 & 532 \\
ES06 & Mahón & 39.87 & 4.32 & 78 \\
ES07 & Víznar & 37.30 & -3.53 & 1265 \\
ES10 & Cabo de Creus & 42.32 & 3.32 & 23 \\
ES12 & Zarra & 39.08 & -1.10 & 885 \\
ES14 & Els Torms & 41.39 & 0.73 & 470 \\
GR02 & Finokalia & 35.31 & 25.66 & 250 \\
MK07 & Lazaropole & 41.32 & 20.42 & 1332 \\
\hline
\end{tabular}

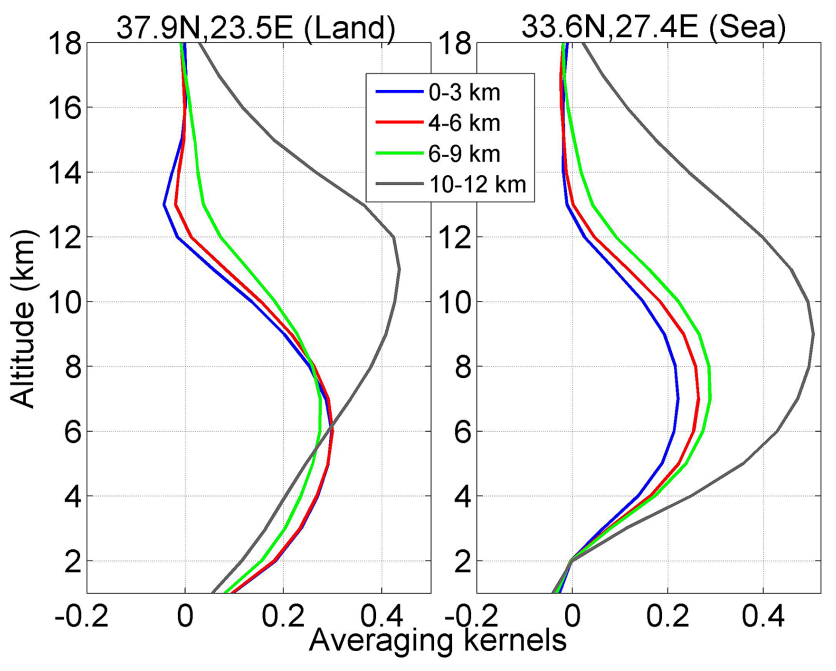

Figure 3. Random $\mathrm{O}_{3}$ averaging kernels over the Mediterranean: the functions are for the [surface-3], [4-6], [6-9], and [10-12] km partial columns characterizing a retrieval for an observation chosen randomly above land (Greece, left panel) and above the sea (right panel) during June 2010.

\subsection{IASI satellite measurements}

The MetOp satellites, launched in October 2006 and September 2012, each carry an IASI instrument, which have been operationally sounding the atmosphere since June 2007 (IASI-1) and January 2013 (IASI-2). The IASI instruments are nadir-looking Fourier transform spectrometers that probe the Earth's atmosphere in the thermal infrared spectral range between 645 and $2760 \mathrm{~cm}^{-1}$, with a spectral resolution of $0.5 \mathrm{~cm}^{-1}$ (apodized) and $0.25 \mathrm{~cm}^{-1}$ spectral sampling. Global distributions of $\mathrm{O}_{3}$ vertical profiles are retrieved in near-real time using a dedicated radiative transfer and retrieval software for the IASI $\mathrm{O}_{3}$ product, the Fast Optimal Retrievals on Layers for IASI (FORLI-O ${ }_{3}$ ) (Hurtmans et al., 2012). The IASI FORLI-O ${ }_{3}$ observations are selected for scenes with cloud coverage below $13 \%$ and with root mean square (rms) of the spectral fit residual lower than $3.5 \times 10^{-8} \mathrm{~W} \mathrm{~cm}^{-2} \mathrm{srcm}^{-1}$. Details about the chemical com- ponents that can be measured by IASI can be found in Clerbaux et al. (2009), Coheur et al. (2009), Turquety et al. (2009), and Clarisse et al. (2011). IASI has the highest $\mathrm{O}_{3}$ sensitivity in the mid- to upper troposphere (Safieddine et al., 2013). Figure 3 shows the partial column averaging kernel function for two specific observations above land and sea during June 2010. It can be seen that the sensitivity to the $\mathrm{O}_{3}$ profile is maximal around $4-10 \mathrm{~km}$ for both observations. IASI sensitivity near the surface is usually limited above the sea, as seen on the right panel of Fig. 3, and better over land, as seen in the left panel, and with corresponding better thermal contrast ( $7.8^{\circ}$ above land, and $1.2^{\circ}$ above sea). IASI is able to detect several pollutants (e.g., carbon monoxide, ammonia, sulfur dioxide, and ammonium sulfate aerosols), especially when a large thermal contrast is combined with stable meteorological conditions, leading to the accumulation of pollutants near the surface (Boynard et al., 2014).

\section{Tropospheric $\mathrm{O}_{3}$ seasonal variation as seen by IASI}

To investigate the seasonal behavior of tropospheric $\mathrm{O}_{3}$ above the Mediterranean, in Fig. 4 we plot the [0-8] km partial tropospheric $\mathrm{O}_{3}$ column as seen by IASI during the period of 2008 to 2013. The data were averaged seasonally, and daytime observations were used since the information content of IASI $\mathrm{O}_{3}$ data is shown to be higher during the day (Clerbaux et al., 2009). We observe a similar tropospheric $\mathrm{O}_{3}$ seasonal behavior each year. The weakest values are observed in winter (DJF) and autumn (SON), when solar activity is minimal. Increasing values in spring (MAM) are due to the increase in $\mathrm{O}_{3}$ production from photochemistry, buildup of winter $\mathrm{O}_{3}$ and its precursors, transport, and/or from $\mathrm{O}_{3}$ of stratospheric origin integrating into the troposphere. The $[0$ $8] \mathrm{km}$ column reaches a maximum in summer (JJA) due to high photochemical $\mathrm{O}_{3}$ production, horizontal transport into the region, or STE, all of which will be investigated in detail in the following sections. Richards et al. (2013) detected a similar spatial distribution with the Global Ozone Monitoring Experiment-2 (GOME-2) during the summers of 2007 and 2008 , with values exceeding $32 \mathrm{DU}$ at the east of the 


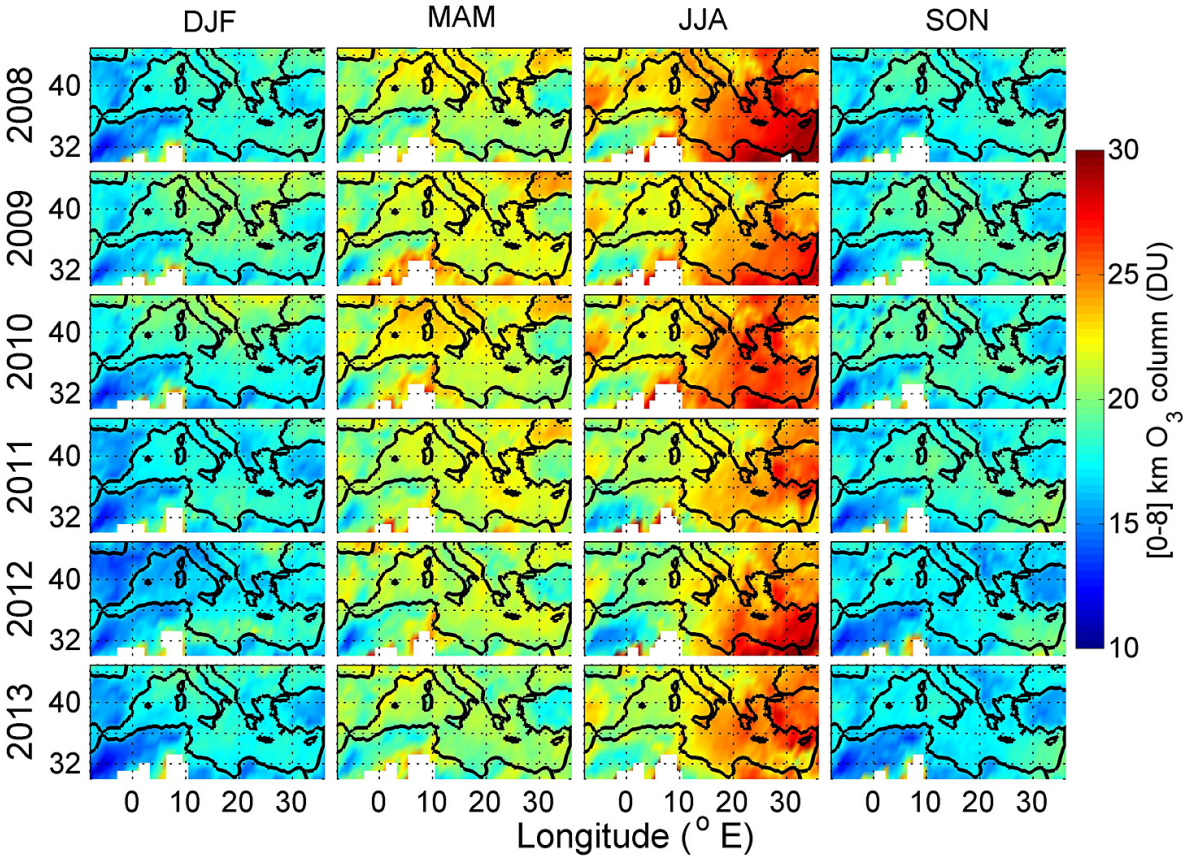

Figure 4. Six-year seasonal variation of [0-8] km integrated IASI $\mathrm{O}_{3}$ column over the Mediterranean region for winter, spring, summer, and autumn. White pixels correspond to a filter applied to poor spectral fits because of emissivity issues in the FORLI radiative transfer above the Sahara.

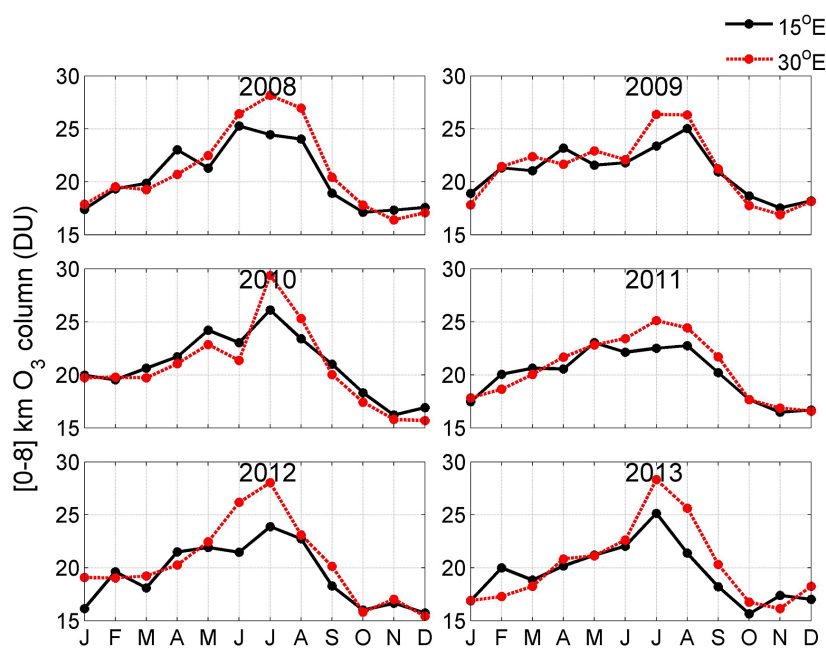

Figure 5. Six-year monthly variation of the integrated $[0-8] \mathrm{km}$ IASI $\mathrm{O}_{3}$ column averaged over $\left[30-45^{\circ} \mathrm{N}\right]$ at $15^{\circ} \mathrm{E}$ (in black) and $30^{\circ} \mathrm{E}$ (in red). Higher summer values are observed to the east of the basin at $30^{\circ} \mathrm{E}$

basin for the [0-6] $\mathrm{km} \mathrm{O}_{3}$ column. To further investigate the higher values detected to the east of the basin, we analyze longitudinal transects of $1^{\circ}$ width along $15^{\circ} \mathrm{E}$ (representing the middle of the basin) and $30^{\circ} \mathrm{E}$ (representing the east of the basin), marked in orange in Fig. 2.
Figure 5 shows that, during the period of 2008 to 2013, the summers in the east of the basin, notably at $30^{\circ} \mathrm{E}$ (plotted in red), are marked by elevated tropospheric [0-8] $\mathrm{km} \mathrm{O}_{3}$ values. The difference between the two $\mathrm{O}_{3}$ columns at the 2 different longitudes was highest $(4.7 \mathrm{DU}-22 \%)$ during June 2012. The highest recorded values were up to $30 \mathrm{DU}$ in July 2010 at $30^{\circ} \mathrm{E}$. This period coincides with the 2010 Russian heat wave (Schubert et al., 2011), which caused severe fires with high $\mathrm{O}_{3}$ precursors emissions (R'Honi et al., 2013). Further discussion is provided in Sect. 4.2

\section{$4 \mathrm{O}_{3}$ budget from the WRF-Chem model during summer 2010}

From this section onwards, we focus our analysis on summer 2010, the year of the anthropogenic emission inventory used in the model. We evaluate the model then we discuss the $\mathrm{O}_{3}$ budget at different altitude levels in the Mediterranean troposphere.

\subsection{Model evaluation: comparison to EMEP and IASI}

The model is evaluated by comparing $\mathrm{O}_{3}$ concentrations with ground $\mathrm{O}_{3}$ data from the EMEP stations (Sect. 2.2) and then free-tropospheric $\mathrm{O}_{3}$ data from IASI (Sect. 2.3). 

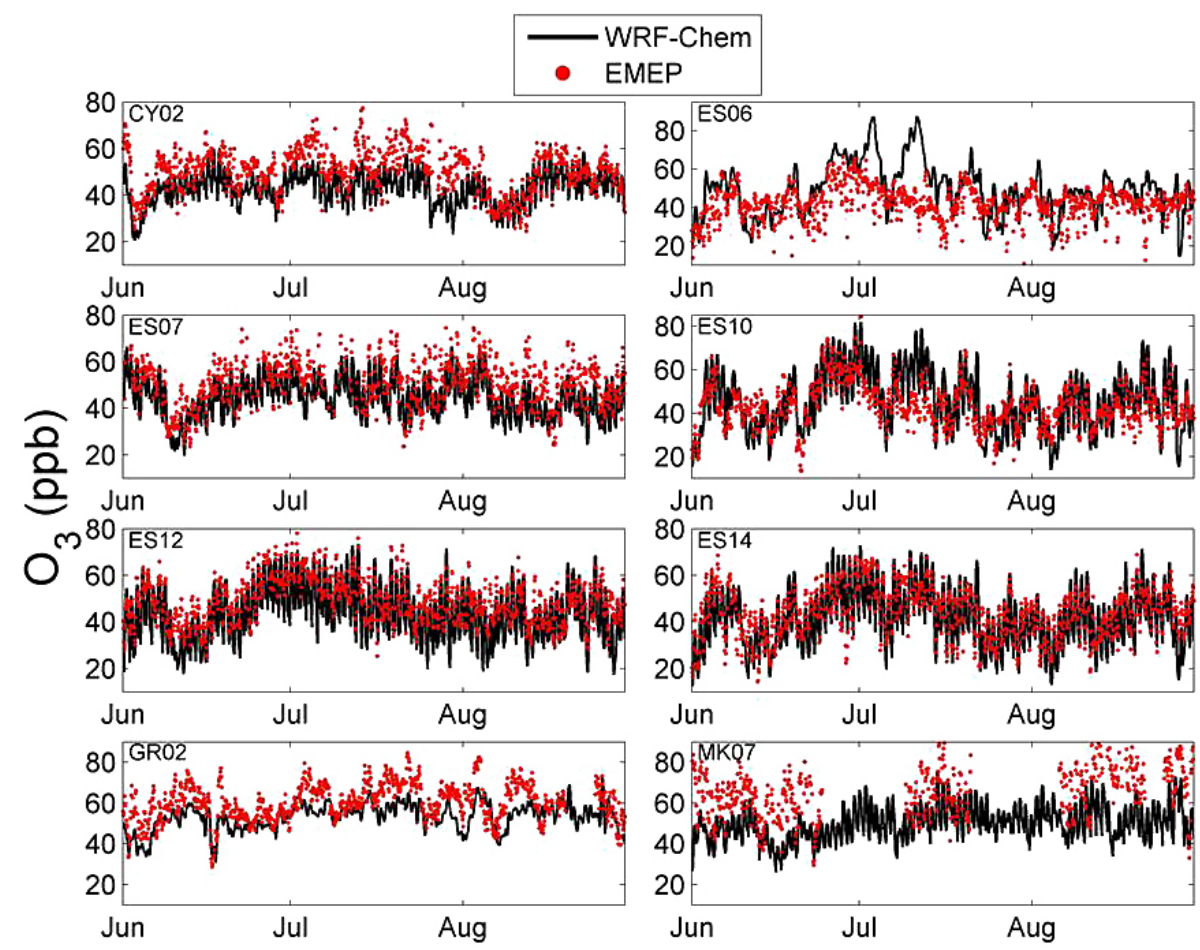

Figure 6. $\mathrm{O}_{3}$ time series of EMEP and WRF-Chem data at the surface for the stations localized in Fig. 2 for the period JJA 2010.

\subsubsection{Comparison to EMEP surface monitoring stations}

Linear spatial interpolation was applied to WRF-Chem data in order to correlate the model outputs and the EMEP data that were averaged every $2 \mathrm{~h}$ to coincide with the model run output data. Figure 6 shows the individual time series of the data of the eight stations used for the validation. Table 2 shows the individual $\mathrm{O}_{3}$ correlation and bias between WRFChem and the EMEP for each of the stations used in this study during JJA 2010. The model simulates the surface $\mathrm{O}_{3}$ with a correlation ranging from 0.41 (ES06) to 0.80 (ES12) and a mean value of 0.52 . Figure 6 and Table 2 show that the model reasonably well reproduces the average amplitude of the daily cycle seen in the observation. For all stations except ES06 and ES10, the model underestimates the ground observation during the summer period with a mean relative error between -23.9 and $-6.4 \%$. The biases reported may be due to the resolution of the model resulting in a grid of around $50 \mathrm{~km}$ around the EMEP rural sites that may include other surface $\mathrm{O}_{3}$ contributions. Other possible reasons include difficulties in simulating local flow patterns due to topography and land-sea circulation, as well as uncertainties in emissions and $\mathrm{NO}_{\mathrm{x}}$ concentrations (Pfister et al., 2013). Our results compare well with the study by Tuccella et al. (2012), which compared WRF-Chem to 75 EMEP stations over Europe during 2007 and found that hourly $\mathrm{O}_{3}$ exhibits a correlation with observations ranging from 0.38 to 0.83 . The largest discrepancy observed, with modeled $\mathrm{O}_{3}$ values larger than
Table 2. Pearson correlation coefficient, bias and the corresponding mean relative error (MRE) of each EMEP and WRF-Chem ground station data localized in Fig. 2, for the period JJA 2010.

\begin{tabular}{llrr}
\hline Station name & $\begin{array}{l}\text { Corr. coeff. with } \\
\text { WRF-Chem }\end{array}$ & $\begin{array}{r}\text { Bias } \\
\text { (ppbv) }\end{array}$ & $\begin{array}{r}\text { MRE } \\
(\%)\end{array}$ \\
\hline CY02 & 0.63 & 7.78 & -14.2 \\
ES06 & 0.41 & +7.26 & +20.9 \\
ES07 & 0.77 & -7.24 & -13.4 \\
ES10 & 0.72 & +1.43 & +3.6 \\
ES12 & 0.80 & -5.96 & -12.7 \\
ES14 & 0.78 & -2.99 & -6.4 \\
GR02 & 0.62 & -7.38 & -11.3 \\
MK07 & 0.57 & -16.65 & -23.9 \\
\hline
\end{tabular}

$80 \mathrm{ppbv}$, is for the station ES06-Mahon $\left(39.87^{\circ} \mathrm{N}, 4.32^{\circ} \mathrm{E}\right)$, which might be due a particular uncertainty in the model emissions or dry deposition over this area.

\subsubsection{Comparison to IASI observations}

Averaged data for summer 2010 are used for the comparison of WRF-Chem and IASI O $\mathrm{O}_{3}$ [4-10] km free-tropospheric column. The modeled profile is first linearly interpolated to the time and location of the retrieval. Then, the averaging kernels associated with each IASI measurement and its a priori profile are applied to the interpolated modeled profile (of around seven layers between 4 and $10 \mathrm{~km}$ ). Figure 7 shows 

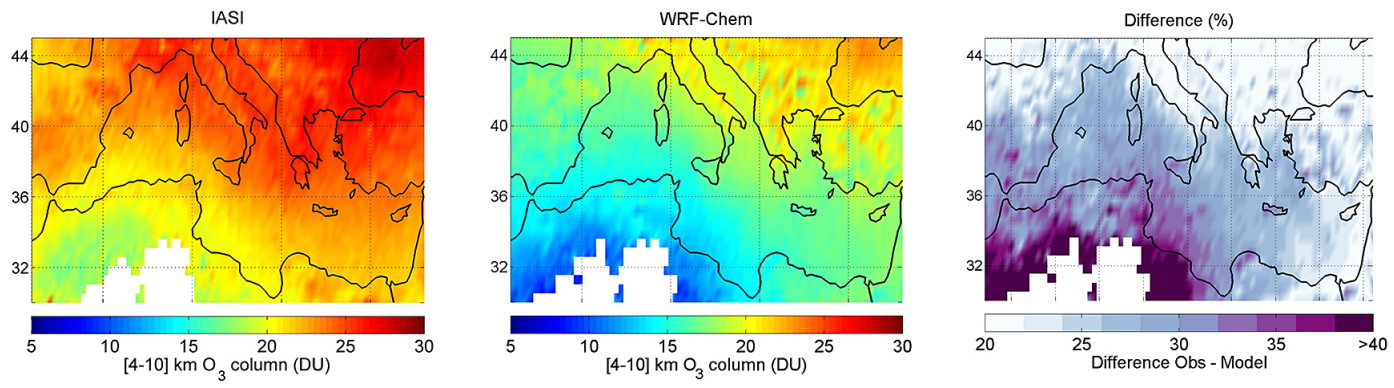

Figure 7. Average [4-10] $\mathrm{km} \mathrm{O}_{3}$ column for JJA 2010 from IASI and WRF-Chem and their relative difference (\%). White pixels correspond to a filter applied to poor spectral fits above the Sahara.

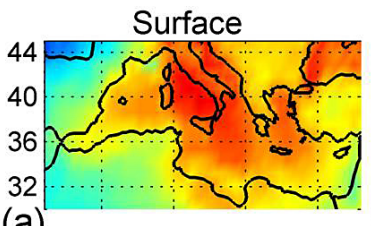

(a)

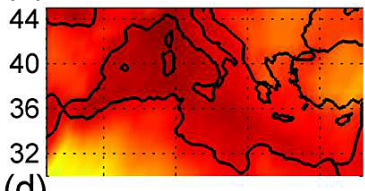

(d)
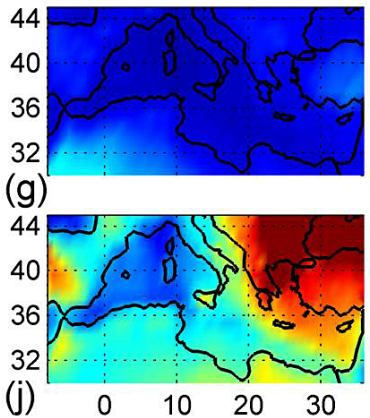

(b)
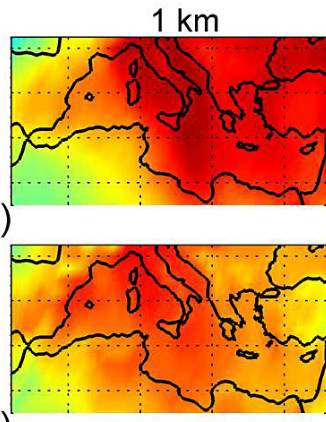

(e)

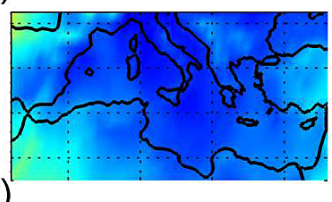

(h)

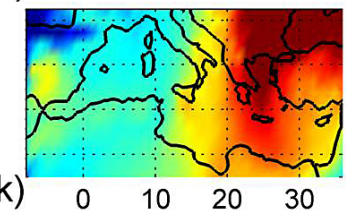

(c)

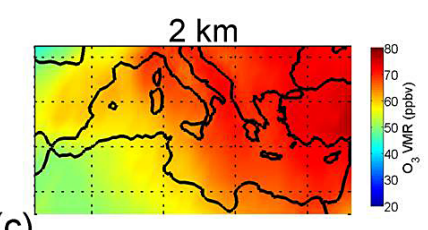

(f)
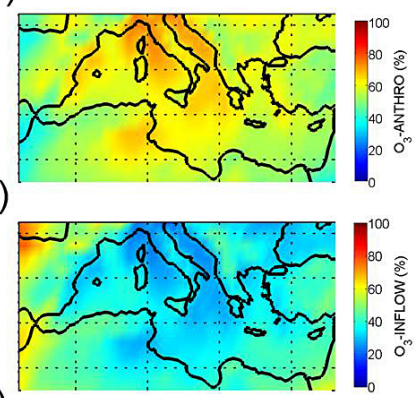

(i)

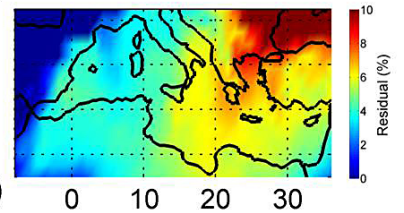

Figure 8. WRF-Chem spatial distributions of (a-c) $\mathrm{O}_{3}$ mixing ratios (ppbv), (d-f) $\mathrm{O}_{3}$ anthropogenic tracer relative contributions (\%), (g-i)

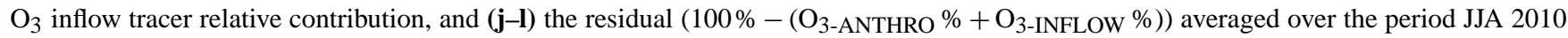
at the surface and 1 and $2 \mathrm{~km}$. Note that the color bar for the residual plots is different.

the spatial distribution of the [4-10] km integrated IASI and WRF-Chem model $\mathrm{O}_{3}$ column along with the relative differences. We chose to analyze this part of the atmosphere in particular because IASI has a better sensitivity between 4 and $10 \mathrm{~km}$ over both land and water as shown in Fig. 3. The model reproduces the spatial patterns seen by IASI during summer (JJA) 2010 well, with a correlation coefficient of about 0.93 and a summertime mean bias of $6.1 \mathrm{DU}(25 \%)$ (not shown). The model underestimation of the [4-10] km $\mathrm{O}_{3}$ column might due to the difficulties in resolving the high $\mathrm{O}_{3}$ concentrations observed in transported plumes over large distances (Pfister et al., 2013). On the other hand, the high discrepancies seen over northern Africa might be due to poor spectral fits from IASI above surfaces with sharp emissivity variations, particularly above the desert (Hurtmans et al.,
2012), leading to a possible overestimation of the real profile. We analyzed the IASI total retrieval error for the [4-10] km partial column (not shown here) and found that it is on average around $7 \%$ in the model domain, and between 7 and $12 \%$ where the discrepancies between the model and IASI are the highest.

\subsection{Origins of boundary layer $\mathrm{O}_{3}$ over the Mediterranean}

Modeled $\mathrm{O}_{3}$ concentrations are illustrated in Fig. 8a-c at the surface and 1 and $2 \mathrm{~km}$ during JJA 2010. At the surface, modeled $\mathrm{O}_{3}$ exhibits the highest values downwind from the European continent. At 1 and $2 \mathrm{~km}$ the whole eastern part of the basin is characterized by high $\mathrm{O}_{3}$ mixing ratios. In 

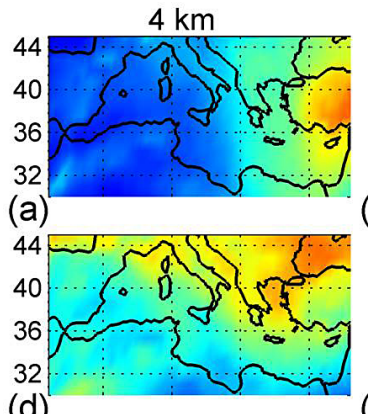

(b)
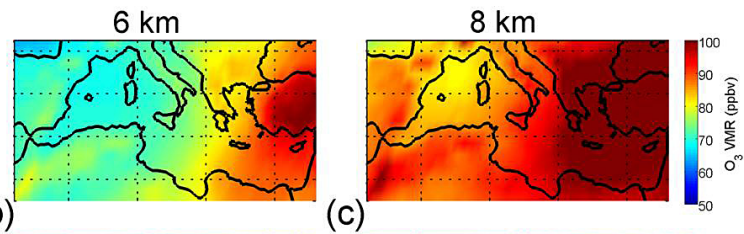

(d)
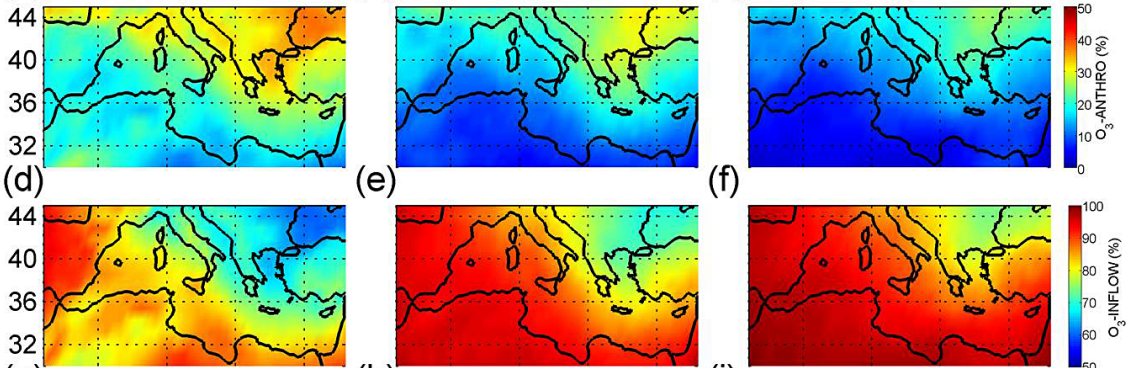

(g)

(e)

(f)
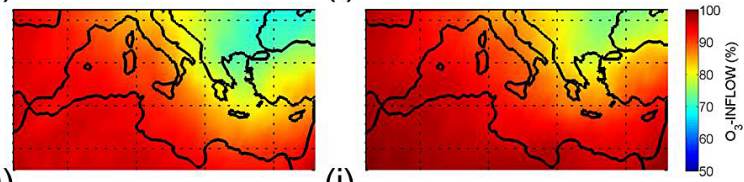

(h)

(i)
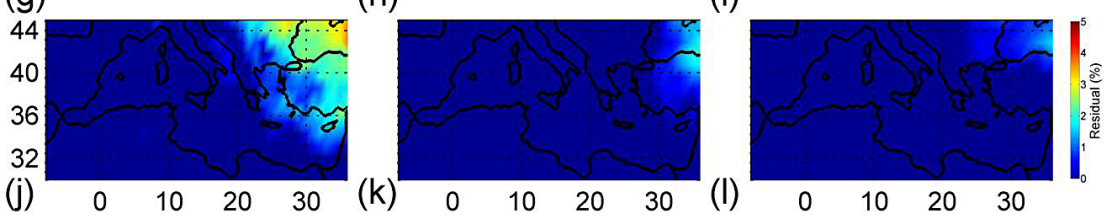

Figure 9. Same as Fig. 8 but for 4, 6, and $8 \mathrm{~km}$.

order to investigate possible sources of high $\mathrm{O}_{3}$, we run the model with two different tracers of pollution, $\mathrm{O}_{3}$-ANTHRO and $\mathrm{O}_{3-\mathrm{INFLOW}}$, as described in Sect. 2.1. O 3 -ANTHRO (Fig. 8df) assesses the possible anthropogenic contribution of $\mathrm{O}_{3}$ at

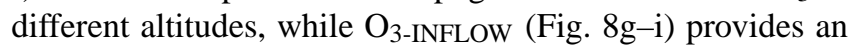
estimate of transport of $\mathrm{O}_{3}$, including the stratosphere. The residual plots plotted in panels $\mathrm{j}-1$ show the completion of the $\mathrm{O}_{3}$ budget, and represent the $\mathrm{O}_{3}$ contribution from fires and biogenic sources. These plots show that the residual contribution is between 0 and $10 \%$, inferring that $\mathrm{O}_{3 \text {-ANTHRO and }}$

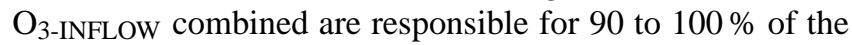
total $\mathrm{O}_{3}$ budget over the model domain at the different altitudes of Fig. 8. The surface shows a high contribution from the anthropogenic emission tracer $\left(\mathrm{O}_{3}\right.$-ANTHRO $\left.>85 \%\right)$, with almost zero contribution from the inflow tracer. This shows the importance of local emissions to the $\mathrm{O}_{3}$ surface concentration. At $1 \mathrm{~km}$, the highest contribution is also for the anthropogenic tracer (up to 75-80\%), whereas the result is mixed at $2 \mathrm{~km}$ between the two tracers (around $50-60 \%$ for

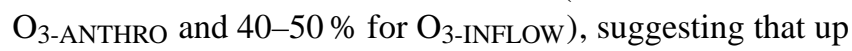
to $50 \%$ of the $\mathrm{O}_{3}$ available at $2 \mathrm{~km}$ is being transported. The rest of the $\mathrm{O}_{3}$ plotted in the residual plots (panels $\mathrm{j}-\mathrm{l}$ ) and decreasing with altitude is suggested to be from fire sources, as the extended domain (Fig. 2a) used in the study includes parts of the region hit by the Russian fires of summer 2010 .

\subsection{Origins of free-tropospheric $\mathrm{O}_{3}$ over the Mediterranean}

$\mathrm{O}_{3}$ concentrations at 4,6 , and $8 \mathrm{~km}$ in Fig. 9a-c show that the eastern part of the basin is subject to much higher $\mathrm{O}_{3}$ values, reaching up to $100 \mathrm{ppbv}$ between 6 and $8 \mathrm{~km}$ (see further discussion in Sect. 5). The anthropogenic contribution decreases with altitude, whereas the $\mathrm{O}_{3}$ inflow contribution increases. The northeastern corner of the modeled domain in panels $\mathrm{d}-\mathrm{f}$ show anthropogenic contribution between 20 and $40 \%$. This might be due to important vertical transport and mixing in the free troposphere. These values can be correlated with the $\mathrm{O}_{3}$ residuals plotted in panels $\mathrm{j}-1$. These panels show an $\mathrm{O}_{3}$ signature in the north eastern corner of the domain. This signature is probably related to the emitted $\mathrm{O}_{3}$ precursors from fires sources in the model domain (Fig. 2) and lifted to the upper troposphere due to convective movements during the Russian fires of summer 2010. We can also suppose that certain anthropogenic $\mathrm{O}_{3}$ precursors, like $\mathrm{NO}_{\mathrm{x}}$, near the fire sources were also transported with the same convective movements to the same part of the domain and eventually contributed to the production of anthropogenic $\mathrm{O}_{3}$ in that region. Panels $\mathrm{g}-\mathrm{i}$ show that 70 to $100 \%$ of the available $\mathrm{O}_{3}$ between 4 and $8 \mathrm{~km}$ does not come from local sources. The high values are likely due to long-range transport of pollution from outside the study region or transport of air masses from the stratosphere, which we will discuss in the following section. The low values recorded in the residual plots in panels $\mathrm{j}-1$ show that the $\mathrm{O}_{3}$ budget in the free troposphere over this region is controlled almost exclusively by local anthropogenic sources and transport. 


\section{WRF-Chem and IASI detection of STE events}

Figures 4 and 5 and Fig. 9a-c showed that the eastern part of the Mediterranean Basin in summer is subject to high $\mathrm{O}_{3}$ mixing ratios at 4,6 , and $8 \mathrm{~km}$. In order to further investigate the sources and processes responsible for these enhancements, modeled and observed IASI $\mathrm{O}_{3}$ vertical profiles in the troposphere were examined, during summer 2010, to try to detect possible STE events.

Figure 10 shows the tropospheric $\mathrm{O}_{3}$ vertical distributions along $15^{\circ} \mathrm{E}$ (mid-Mediterranean) and $30^{\circ} \mathrm{E}$ (eastern Mediterranean) for IASI (panels a and b) and WRF-Chem, smoothed with the IASI averaging kernels (panels $\mathrm{c}$ and d) for JJA 2010. Between 4 and $8 \mathrm{~km}$, panels $\mathrm{b}$ and $\mathrm{d}$ show higher values of $\mathrm{O}_{3}$ in the eastern part of the basin $\left(30^{\circ} \mathrm{E}\right)$, with concentrations ranging between 50 and $100 \mathrm{ppbv}$ for IASI and 40 to $100 \mathrm{ppbv}$ for WRF-Chem (WRF-Chem underestimates IASI as shown in Fig. 7).

Since stratospheric intrusions within the regional domain are included in the $\mathrm{O}_{3 \text {-INFLOW }}$ tracer, it is useful to use other stratospheric tracers to distinguish the transport from the stratosphere. The potential vorticity (PV) and the water vapor mixing ratio $\left(Q_{\text {vap }}\right)$ measurements can be used as markers of transport from the upper troposphere-lower stratosphere (UTLS) to the troposphere: elevated $\mathrm{O}_{3}$ and PV, as well as low $Q_{\text {vap }}$ values, would indicate that high freetropospheric values are due to downward transport from the UTLS (Holton et al., 1995). Here, we study PV and $Q_{\text {vap }}$ at $4,6,8$, and $10 \mathrm{~km}$ calculated from the WRF-Chem model run parameters. Figure 11 shows that, starting at $4 \mathrm{~km}$, higher PV and lower $Q_{\text {vap }}$ values start to develop to the east of the basin. At 8 and $10 \mathrm{~km}$, the highest PV values (1.5 to 2 potential vorticity units (pvu); $1 \mathrm{pvu}=10^{-6} \mathrm{~m}^{2} \mathrm{~K} \mathrm{~kg}^{-1} \mathrm{~s}^{-1}$ ) and the lowest $Q_{\text {vap }}$ values $\left(0-0.10 \mathrm{~g} \mathrm{~kg}^{-1}\right)$ are recorded to the east of the basin, in comparison with low PV values in the middle of and to the west of the basin $(0.5-1)$ with high $Q_{\text {vap values }}$ $(0.1-0.15)$. The high PV/low $Q_{\text {vap }}$ values to the east are in accordance with Figs. 9 and 10, strongly suggesting that this part of the basin is subject to transport from the UTLS into the free troposphere. In fact, at $30^{\circ} \mathrm{E}$ and around $37-39^{\circ} \mathrm{N}$ (panels $b$ and $d$ of Fig. 10), both IASI and the model suggest a stratospheric intrusion. This intrusion corresponds to $\mathrm{PV}$ values between 1.4 and 2 pvu at $8 \mathrm{~km}$ and $Q_{\text {vap values around }}$ $0.05 \mathrm{~g} \mathrm{~kg}^{-1}$. In a recent study, Zanis et al. (2014), using a 12year climatology (1998-2009) of the ERA-interim reanalysis, also detected frequent events of STE with PV ranging between 0.4 and 1.4 pvu and specific humidity values between 0.01 and $2 \mathrm{~g} \mathrm{~kg}^{-1}$ between 700 and $250 \mathrm{hPa}$ during July and August to the east of the basin, in accordance with our results for summer 2010 at 4,6 , and $8 \mathrm{~km}$.
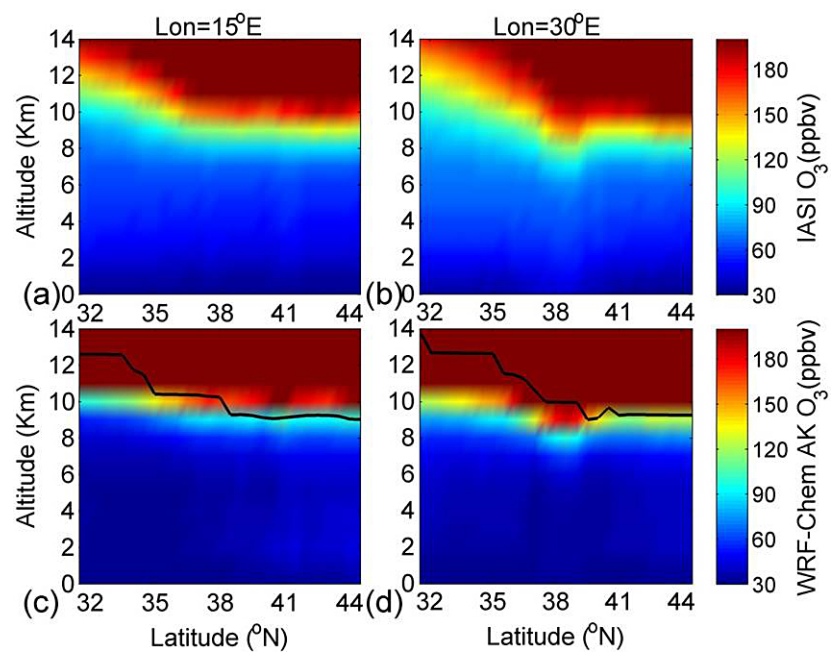

Figure 10. Mean latitude-altitude cross sections of IASI $\mathrm{O}_{3}$ (ab) and modeled $\mathrm{O}_{3}$ (c-d) averaged over JJA 2010 at $15^{\circ} \mathrm{E}$ (left) and $30^{\circ} \mathrm{E}$ (right). The black line corresponds to the dynamical tropopause height.

\section{Discussion and conclusions}

Six years of tropospheric $\mathrm{O}_{3}$ observations provided by the IASI mission above the Mediterranean are shown. Tropospheric [0-8] $\mathrm{km} \mathrm{O}_{3}$ columns show a consistent seasonal behavior over the period 2008-2013, with pronounced maxima in summer and with higher values to the east of the basin. A complementary study by Doche et al. (2014) using IASI data at $3 \mathrm{~km}$ height also showed 6-year recurrent $\mathrm{O}_{3}$ summer maxima in July to the east of the basin. Since IASI has a lower sensitivity in the lower troposphere and above the sea, the anthropogenic emission contribution to the boundary layer $\mathrm{O}_{3}$ is not well captured by the instrument. However, IASI is able to detect high tropospheric $\mathrm{O}_{3}$ values in the free to upper troposphere, where its sensitivity is the highest, to the east of the basin during the 6 years. Focusing on summer 2010, we use IASI and the regional chemical transport model WRFChem to interpret these maxima. A tagging scheme is used to keep track of $\mathrm{O}_{3}$ from anthropogenic sources in the domain $\left(\mathrm{O}_{3}\right.$-ANTHRO $)$ and $\mathrm{O}_{3}$ from inflow at the domain boundaries and stratosphere $\left(\mathrm{O}_{3}\right.$-INFLOW $)$. Our results show that transport plays an essential role in the $\mathrm{O}_{3}$ budget over the Mediterranean troposphere and that summer $\mathrm{O}_{3}$ maxima over the region are especially recorded in the eastern part of the basin. Even though high local anthropogenic emissions are responsible for $60-100 \%$ of $\mathrm{O}_{3}$ in the boundary layer (surface$2 \mathrm{~km}$ ), as demonstrated by the anthropogenic $\mathrm{O}_{3}$ tracer of the WRF-Chem model, $\mathrm{O}_{3}$ is mainly transported above $2 \mathrm{~km}$. Kalabokas et al. $(2007,2013)$ showed that the highest ozone concentrations in the lower troposphere are associated with large-scale subsidence of ozone-rich air masses from the upper troposphere. However, Zanis et al. (2014), using model simulations, reported that long-distance transport and local 

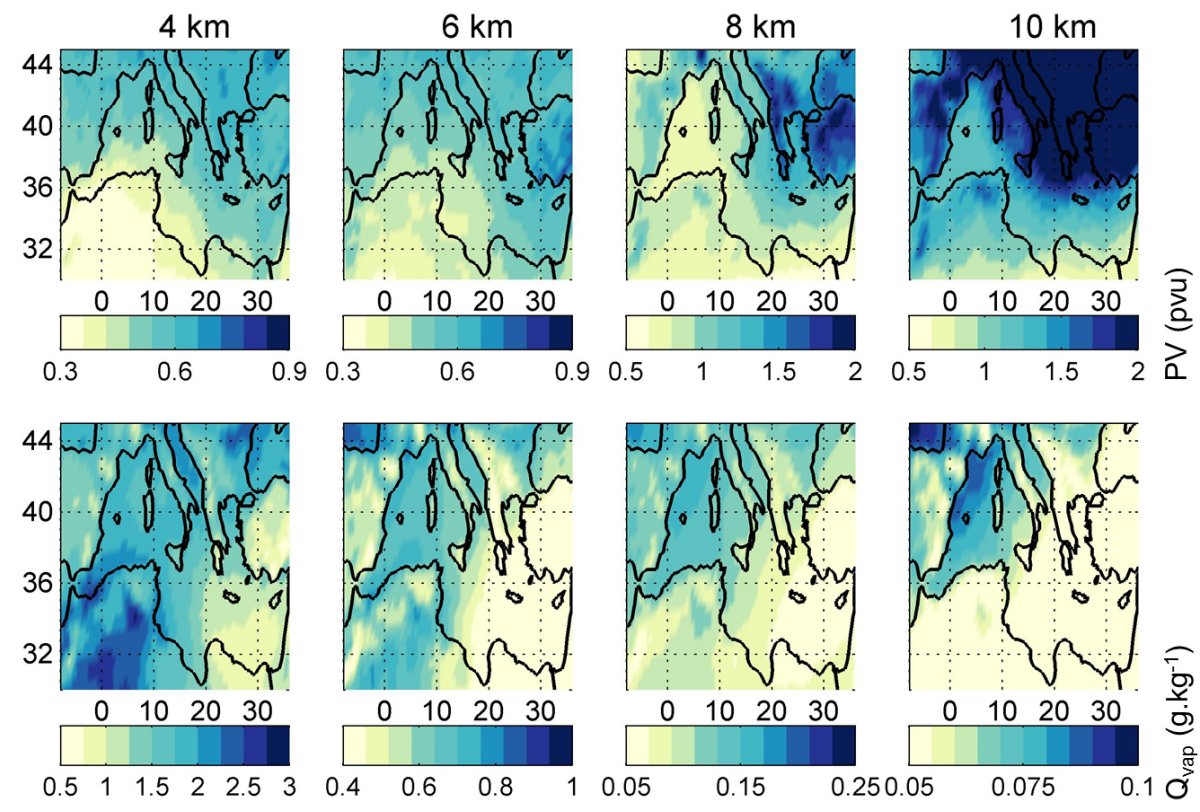

Figure 11. WRF-Chem (a) potential vorticity (PV) at 4, 6, 8, and $10 \mathrm{~km}$ over the Mediterranean region for JJA 2010 and (b) the water vapor mixing ratio $\left(Q_{\mathrm{vap}}\right)$ for the same vertical levels and time period.

photochemical processes dominate at the low troposphere.In this study and in the free troposphere, WRF-Chem shows that vertical and lateral transport of $\mathrm{O}_{3}$ (represented by the $\mathrm{O}_{3-\mathrm{INFLOW}}$ tracer) is responsible for $70-100 \%$ of $\mathrm{O}_{3}$ at 4,6 , and $8 \mathrm{~km}$. In the eastern Mediterranean, Roelofs et al. (2003) showed important contributions to elevated $\mathrm{O}_{3}$ in the middle troposphere by transport from the stratosphere. More recently, Hess and Zbinden (2013) showed that stratospheric interannual $\mathrm{O}_{3}$ variability significantly drives the $\mathrm{O}_{3}$ variability in the middle troposphere between 30 and $90^{\circ} \mathrm{N}$, but not the overall trend, which is largely affected by transport processes. The increase in $\mathrm{O}_{3}$ seen by the model and the IASI instrument in the eastern part of the Mediterranean Basin suggests that stratosphere-to-troposphere exchange (STE) events contribute to elevated ozone in the upper free troposphere. This is further shown in the WRF-Chem simulations that predict elevated potential vorticity (PV) and water vapor mixing ratio $\left(Q_{\text {vap }}\right)$ over the same region. This result is in agreement with many previous studies (e.g., Butkovic et al., 1990; Kalabokas and Bartzis, 1998; Kalabokas et al., 2000, 2007; Kouvarakis et al., 2000; Lelieveld et al., 2002; Sprenger and Wernli, 2003; Papayannis et al., 2005; Gerasopoulos et al., 2006b; Akritidis et al., 2010; Zanis et al., 2014; Doche et al., 2014) that have shown the occurrence of STE events in the eastern Mediterranean region in summer. Since $\mathrm{O}_{3}$ maxima have the potential to strongly impact regional air quality and climate (e.g., Hauglustaine and Brasseur, 2001), the present study further demonstrates the importance of quantifying and analyzing $\mathrm{O}_{3}$ and its sources at different altitudes in the atmosphere. Quantification of long-term trends and distinguishing between the different sources are crucial. This should be possible with observations and model runs over longer timescales with additional tracers to identify all $\mathrm{O}_{3}$ sources.

Acknowledgements. IASI is a joint mission of EUMETSAT and the Centre National d'Etudes Spatiales (CNES, France). The IASI L1 data are distributed in near-real time by EUMETSAT through the EumetCast distribution system. The authors acknowledge the French Ether atmospheric database administrators (www.pole-ether.fr) for providing the IASI L1C data and L2 temperature data. This work was undertaken under the auspices of the O3M-SAF project of the EUMETSAT and supported by the European Space Agency (ozone CCI project). The French scientists are grateful to CNES and Centre National de la Recherche Scientifique (CNRS) for financial support. The research in Belgium is funded by the Belgian State Federal Office for Scientific, Technical and Cultural Affairs and the European Space Agency (ESA Prodex arrangement). P. F. Coheur is a senior research associate with F.R.S-FNRS. Support is also acknowledged from the EU FP7 ECLIPSE (Evaluating the Climate and Air Quality Impacts of Short-Lived Pollutants) project (no. 282688).

Edited by: J. Ma 


\section{References}

Akritidis, D., Zanis, P., Pytharoulis, I., Mavrakis, A., and Karacostas, T.: A deep stratospheric intrusion event down to the earth's surface of the megacity of Athens, Meteorol. Atmos. Phys., 109, 9-18, doi:10.1007/s00703-010-0096-6, 2010.

Boynard, A., Clerbaux, C., Clarisse, L., Safieddine, S., Pommier M., Van Damme, M., Bauduin, S., Oudot, C., Hadji-Lazaro, J., Hurtmans, D., and Coheur, P.-F.: First simultaneous space measurements of atmospheric pollutants in the boundary layer from IASI: a case study in the North China Plain, Geophys. Res. Lett., 41, 645-651 doi:10.1002/2013GL058333, 2014.

Butkovic, V., Cvitas, T., and Klasinc, L.: Photochemical ozone in the Mediterranean, Sci. Total Environ., 99, 145-151, doi:10.1016/0048-9697(90)90219-k, 1990.

Chameides, W. and Walker, J. C. G.: A photochemical theory of tropospheric ozone, J. Geophys. Res., 78, 8751-8760, 1973.

Chin, M., Ginoux, P., Kinne, S., Torres, O., Holben, B. N., Duncan, B. N., Martin, R. V., Logan, J. A., Higurashi, A., and Nakajima, T.: Tropospheric aerosol optical thickness from the GOCART model and comparisons with satellite and Sun photometer measurements, J. Atmos. Sci., 59, 461-483, 2002.

Clarisse, L., R'Honi, Y., Coheur, P.-F., Hurtmans, D., and Clerbaux, C.: Thermal infrared nadir observations of 24 atmospheric gases, Geophys. Res. Lett., 38, L10802, doi:10.1029/2011GL047271, 2011.

Clerbaux, C., Boynard, A., Clarisse, L., George, M., Hadji-Lazaro, J., Herbin, H., Hurtmans, D., Pommier, M., Razavi, A., Turquety, S., Wespes, C., and Coheur, P.-F.: Monitoring of atmospheric composition using the thermal infrared IASI/MetOp sounder, Atmos. Chem. Phys., 9, 6041-6054, doi:10.5194/acp-9-6041-2009, 2009.

Coheur, P.-F., Clarisse, L., Turquety, S., Hurtmans, D., and Clerbaux, C.: IASI measurements of reactive trace species in biomass burning plumes, Atmos. Chem. Phys., 9, 5655-5667, doi:10.5194/acp-9-5655-2009, 2009.

Crutzen, P. J.: A discussion of the chemistry of some minor constituents in the stratosphere and troposphere, Pure Appl. Geophys., 106-108, 1385, 1973.

Doche, C., Dufour, G., Foret, G., Eremenko, M., Cuesta, J., Beekmann, M., and Kalabokas, P.: Summertime tropospheric ozone variability over the Mediterranean basin observed with IASI, Atmos. Chem. Phys. Discuss., 14, 13021-13058, doi:10.5194/acpd-14-13021-2014, 2014.

EEA: Air Quality in Europe - 2012 Report, European Environment Agency, ISBN:978-92-9213-328-3, Luxembourg, Office for Official Publications of the European Union, doi:10.2800/55823, 2012.

Emmons, L. K., Walters, S., Hess, P. G., Lamarque, J.-F., Pfister, G. G., Fillmore, D., Granier, C., Guenther, A., Kinnison, D., Laepple, T., Orlando, J., Tie, X., Tyndall, G., Wiedinmyer, C., Baughcum, S. L., and Kloster, S.: Description and evaluation of the Model for Ozone and Related chemical Tracers, version 4 (MOZART-4), Geosci. Model Dev., 3, 43-67, doi:10.5194/gmd3-43-2010, 2010a.

Emmons, L. K., Apel, E. C., Lamarque, J.-F., Hess, P. G., Avery, M., Blake, D., Brune, W., Campos, T., Crawford, J., DeCarlo, P. F., Hall, S., Heikes, B., Holloway, J., Jimenez, J. L., Knapp, D. J., Kok, G., Mena-Carrasco, M., Olson, J., O’Sullivan, D., Sachse, G., Walega, J., Weibring, P., Weinheimer, A., and Wiedinmyer,
C.: Impact of Mexico City emissions on regional air quality from MOZART-4 simulations, Atmos. Chem. Phys., 10, 6195-6212, doi:10.5194/acp-10-6195-2010, 2010b.

Emmons, L. K., Hess, P. G., Lamarque, J.-F., and Pfister, G. G.: Tagged ozone mechanism for MOZART-4, CAM-chem and other chemical transport models, Geosci. Model Dev., 5, 15311542, doi:10.5194/gmd-5-1531-2012, 2012.

Fiore, A. M., Jacob, D. J., Bey, I., Yantosca, R. M., Field, B. D., Fusco, A. C., and Wilkinson, J. G.: Background ozone over the United States in summer: Origin, trend, and contribution to pollution episodes, J. Geophys. Res., 107, 4275, doi:10.1029/2001JD000982, 2002.

Fujino, J., Nair, R., Kainuma, M., Masui, T., and Matsuoka, Y.: Multi-gas mitigation analysis on stabilization scenarios using AIM global model, multigas mitigation and climate policy, Energ. J., 27, 343-353, 2006.

Galani, E., Balis, D., Zanis, P., Zerefos, C., Papayannis, A., Wernli, H., and Gerasopoulos, E.: Observations of stratospheretroposphere transport events over the eastern Mediterranean using a ground-based lidar system, J. Geophys. Res., 108, D128527, doi:10.1029/2002JD002596, 2003.

Gerasopoulos, E., Zanis, P., Stohl, A., Zerefos, C. S., Papastefanou, C., Ringer,W., Tobler, L., Huebener, S., Kanter, H. J., Tositti, L., and Sandrini, S.: A climatology of 7Be at four high-altitude stations at the Alps and the Northern Apennines, Atmos. Environ., 35, 6347-6360, 2001.

Gerasopoulos, E., Kouvarakis, G., Vrekoussis, M., Kanakidou, M., Mihalopoulos, N.: Ozone variability in the marine boundary layer of the Eastern Mediterranean based on 7-year observations, J. Geophys. Res., 110, D15309, doi:10.1029/2005JD005991, 2005.

Gerasopoulos, E., Kouvarakis, G., Vrekoussis, M., Donoussis, C., Mihalopoulos, N., and Kanakidou, M.: Photochemical ozone production in the Eastern Mediterranean, Atmos. Environ., 40, 3057-3069, 2006a.

Gerasopoulos, E., Zanis, P., Papastefanou, C., Zerefos, C. S., Ioannidou, A., and Wernli, H.: A complex case study of down to the surface intrusions of persistent stratospheric air over the Eastern Mediterranean, Atmos. Environ., 40, 4113-4125, 2006b.

Grell, G. A., Peckham, S. E., Schmitz, R., McKeen, S. A., Frost, G., Skamarock, W. C., and Eder, B.: Fully coupled "online" chemistry within the WRF model, Atmos. Environ., 39, 6957-6975, 2005.

Guenther, A., Karl, T., Harley, P., Wiedinmyer, C., Palmer, P. I., and Geron, C.: Estimates of global terrestrial isoprene emissions using MEGAN (Model of Emissions of Gases and Aerosols from Nature), Atmos. Chem. Phys., 6, 3181-3210, doi:10.5194/acp-63181-2006, 2006.

Hess, P. G. and Zbinden, R.: Stratospheric impact on tropospheric ozone variability and trends: 1990-2009, Atmos. Chem. Phys., 13, 649-674, doi:10.5194/acp-13-649-2013, 2013.

Hijioka, Y., Matsuoka, Y., Nishimoto, H., Matsui, M., and Kanuma, M.: Global GHG emissions scenarios under GHG concentration stabilization targets, Journal of Global Environmental Engineering, 13, 97-108, 2008.

Hjellbrekke, A., Solberg, S., and Fjæraa, A. M.: Ozone measurements 2010 EMEP/CCC-Report 2/2012, available at: http: //www.nilu.no/projects/ccc/reports/cccr2-2012.pdf (last access: 13 May 2014), 2012. 
Hodnebrog, Ø., Solberg, S., Stordal, F., Svendby, T. M., Simpson, D., Gauss, M., Hilboll, A., Pfister, G. G., Turquety, S., Richter, A., Burrows, J. P., and Denier van der Gon, H. A. C.: Impact of forest fires, biogenic emissions and high temperatures on the elevated Eastern Mediterranean ozone levels during the hot summer of 2007, Atmos. Chem. Phys., 12, 8727-8750, doi:10.5194/acp12-8727-2012, 2012.

Hauglustaine, D. A. and Brasseur, G. P.: Evolution of tropospheric ozone under anthropogenic activities and associated radiative forcing of climate, J. Geophys. Res.-Atmos., 106, 32337-32360, doi:10.1029/2001jd900175, 2001.

Holton, J. R., Haynes, P. H., McIntyre, E. M., Douglass, A. R., Rood, R. B., and Pfister, L.: Stratosphere-troposphere exchange, Rev. Geophys., 33, 403-439, 1995.

Hurtmans, D., Coheur, P.-F., Wespes, C., Clarisse, L., Scharf, O., Clerbaux, C., Hadji-Lazaro, J., George, M., and Turquety, S.: FORLI radiative transfer and retrieval code for IASI, J. Quant. Spectrosc. Ra., 113, 1391-1408, 2012.

Im, U., Markakis, K., Poupkou, A., Melas, D., Unal, A., Gerasopoulos, E., Daskalakis, N., Kindap, T., and Kanakidou, M.: The impact of temperature changes on summer time ozone and its precursors in the Eastern Mediterranean, Atmos. Chem. Phys., 11, 3847-3864, doi:10.5194/acp-11-3847-2011, 2011.

Kalabokas, P. D. and Bartzis, J. G.: Photochemical air pollution characteristics at the station of the NCSR-Demokritos, during the MEDCAPHOT-TRACE campaign in Athens, Greece (20 August to 20 September 1994), Atmos. Environ., 32, 2123-2139, doi:10.1016/s1352-2310(97)00423-8, 1998.

Kalabokas, P. D., Viras, L. G., Bartzis, J. G., and Repapis, C. C.: Mediterranean rural ozone characteristics around the urban area of Athens, Atmos. Environ., 34, 5199-5208, doi:10.1016/s13522310(00)00298-3, 2000.

Kalabokas, P. D., Volz-Thomas, A., Brioude, J., Thouret, V., Cammas, J.-P., and Repapis, C. C.: Vertical ozone measurements in the troposphere over the Eastern Mediterranean and comparison with Central Europe, Atmos. Chem. Phys., 7, 3783-3790, doi:10.5194/acp-7-3783-2007, 2007.

Kalabokas, P. D., Cammas, J.-P., Thouret, V., Volz-Thomas, A., Boulanger, D., and Repapis, C. C.: Examination of the atmospheric conditions associated with high and low summer ozone levels in the lower troposphere over the eastern Mediterranean, Atmos. Chem. Phys., 13, 10339-10352, doi:10.5194/acp-1310339-2013, 2013.

Kouvarakis, G., Tsigaridis, K., Kanakidou, M., and Mihalopoulos, N.: Temporal variations of surface regional background ozone over Crete Island in the southeast Mediterranean, J. Geophys. Res., 105, 4399-4407, 2000.

Lamarque, J.-F., Hess, P. G., Emmons, L., Buja, L., Washington, W., and Granier, C.: Tropospheric ozone evolution between 1890 and 1990, J. Geophys. Res., 110, D08304, doi:10.1029/2004JD005537, 2005.

Lelieveld, J., Berresheim, H., Borrmann, S., Crutzen, P. J., Dentener, F. J., Fischer, H., Feichter, J., Flatau, P. J., Heland, J., Holzinger, R., Korrmann, R., Lawrence, M. G., Levin, Z., Markowicz, K. M., Mihalopoulos, N., Minikin, A., Ramanathan, V., de Reus, M., Roelofs, G. J., Scheeren, H. A., Sciare, J., Schlager, H., Schultz, M., Siegmund, P., Steil, B., Stephanou, E. G., Stier, P., Traub, M.,Warneke, C.,Williams, J., and Ziereis, H.:
Global air pollution crossroads over the mediterranean, Science, 298, 794-799, doi:10.1126/science.1075457, 2002.

Liu, J., Jones, D. B. A., Zhang, S., and Kar, J.: Influence of interannual variations in transport on summertime abundances of ozone over the Middle East, J. Geophys. Res., 116, D20310, doi:10.1029/2011JD016188, 2011.

Ma, J., Zhou, X., and Hauglustaine, D.: Summertime tropospheric ozone over China simulated with a regional chemical transport model, Part 2. Source contribution and budget, J. Geophys. Res., 107, 4612, doi:10.1029/2001JD001355, 2002.

Papayannis, A., Balis, D., Zanis, P., Galani, E., Wernli, H., Zerefos, C., Stohl, A., Eckhardt, S., and Amiridis, V.: Sampling of an STT event over the Eastern Mediterranean region by lidar and electrochemical sonde, Ann. Geophys., 23, 2039-2050, doi:10.5194/angeo-23-2039-2005, 2005.

Pfister, G., Emmons, L. K., Hess, P. G., Honrath, R., Lamarque, J.-F., Val Martin, M., Owen, R. C., Avery, M., Browell, E. V., Holloway, J. S., Nedelec, P., Purvis, R., Rywerson, T. B., Sachse, G. W., and Schlager, H.: Ozone production from the 2004 North American boreal fires, J. Geophys. Res., 111, D24S07, doi:10.1029/2006JD007695, 2006.

Pfister, G. G., Emmons, L. K., Hess, P. G., Lamarque, J.-F., Thompson, A. M., and Yorks, J. E.: Analysis of the summer 2004 ozone budget over the United States using Intercontinental Transport Experiment Ozonesonde Network Study (IONS) observations and Model of Ozone and Related Tracers (MOZART-4) simulations, J. Geophys. Res., 113, D23306, doi:10.1029/2008JD010190, 2008.

Pfister, G. G., Walters, S., Emmons, L. K., Edwards, D. P., and Avise, J.: Quantifying the contribution of inflow on surface ozone over California during summer 2008, J. Geophys. Res. Atmos., 118, 12282-12299, doi:10.1002/2013JD020336, 2013.

R'Honi, Y., Clarisse, L., Clerbaux, C., Hurtmans, D., Duflot, V., Turquety, S., Ngadi, Y., and Coheur, P.-F.: Exceptional emissions of $\mathrm{NH}_{3}$ and $\mathrm{HCOOH}$ in the 2010 Russian wildfires, Atmos. Chem. Phys., 13, 4171-4181, doi:10.5194/acp-13-41712013, 2013.

Richards, N. A. D., Arnold, S. R., Chipperfield, M. P., Miles, G., Rap, A., Siddans, R., Monks, S. A., and Hollaway, M. J.: The Mediterranean summertime ozone maximum: global emission sensitivities and radiative impacts, Atmos. Chem. Phys., 13, 2331-2345, doi:10.5194/acp-13-2331-2013, 2013.

Rodwell, M. J. and Hoskins, B. J.: Monsoons and the dynamics of deserts, Q. J. R. Meteorol. Soc., 122, 1385-1404, doi:10.1002/qj.49712253408, 1996.

Rodwell, M. J. and Hoskins, B. J.: Subtropical anticyclones and summer monsoons, J. Climate, 14, 3192-3211, 2001

Roelofs, G. J., Scheeren, H. A., Heland, J., Ziereis, H., and Lelieveld, J.: A model study of ozone in the eastern Mediterranean free troposphere during MINOS (August 2001), Atmos. Chem. Phys., 3, 1199-1210, doi:10.5194/acp-3-1199-2003, 2003.

Safieddine, S., Clerbaux, C., George, M., Hadji-Lazaro, J., Hurtmans, D., Coheur, P.-F., Wespes, C., Loyola, D., Valks, P., and Hao, N.: Tropospheric ozone and nitrogen dioxide measurements in urban and rural regions as seen by IASI and GOME-2, J. Geophys. Res.-Atmos., 118, 10555-10566, 2013. 
Schubert, S., Wang, H., and Suarez, M.: Warm season sub-seasonal variability and climate extremes in the Northern Hemisphere: the role of stationary Rossby waves, J. Climate, 24, 4773-4792, 2011.

Sprenger, M. and Wernli, H.: A northern hemispheric climatology of cross-tropopause exchange for the ERA15 time period (19791993), J. Geophys. Res., 108, 8521, doi:10.1029/2002JD002636, 2003.

Stohl, A., Spichtinger-Rakowsky, N., Bonasoni, P., Feldmann, H., Memmesheimer, M., Scheel, H. E., Trickl, T., Hubener, S. H., Ringer, W., and Mandl, M.: The influence of stratospheric intrusions on alpine ozone concentrations, Atmos. Environ., 34, 1323-1354, 2000.

Tuccella, P., Curci, G., Visconti, G., Bessagnet, B., Menut, L., and Park, R. J.: Modeling of gas and aerosol with WRF/Chem over Europe: Evaluation and sensitivity study, J. Geophys. Res., 117, D03303, doi:10.1029/2011JD016302, 2012.

Turquety, S., Hurtmans, D., Hadji-Lazaro, J., Coheur, P.-F., Clerbaux, C., Josset, D., and Tsamalis, C.: Tracking the emission and transport of pollution from wildfires using the IASI CO retrievals: analysis of the summer 2007 Greek fires, Atmos. Chem. Phys., 9, 4897-4913, doi:10.5194/acp-9-4897-2009, 2009.

Tyrlis, E., Lelieveld, J., and Steil, B.: The summer circulation in the eastern Mediterranean and the Middle East: influence of the South Asian Monsoon, Clim. Dynam., 40, 1103-1123, doi:10.1007/s00382-012-1528-4, 2013.
Wespes, C., Emmons, L., Edwards, D. P., Hannigan, J., Hurtmans, D., Saunois, M., Coheur, P.-F., Clerbaux, C., Coffey, M. T., Batchelor, R. L., Lindenmaier, R., Strong, K., Weinheimer, A. J., Nowak, J. B., Ryerson, T. B., Crounse, J. D., and Wennberg, P. O.: Analysis of ozone and nitric acid in spring and summer Arctic pollution using aircraft, ground-based, satellite observations and MOZART-4 model: source attribution and partitioning, Atmos. Chem. Phys., 12, 237-259, doi:10.5194/acp-12-237-2012, 2012.

Wiedinmyer, C., Akagi, S. K., Yokelson, R. J., Emmons, L. K., AlSaadi, J. A., Orlando, J. J., and Soja, A. J.: The Fire INventory from NCAR (FINN): a high resolution global model to estimate the emissions from open burning, Geosci. Model Dev., 4, 625641, doi:10.5194/gmd-4-625-2011, 2011.

Zanis, P., Hadjinicolaou, P., Pozzer, A., Tyrlis, E., Dafka, S., Mihalopoulos, N., and Lelieveld, J.: Summertime free-tropospheric ozone pool over the eastern Mediterranean/Middle East, Atmos. Chem. Phys., 14, 115-132, doi:10.5194/acp-14-115-2014, 2014.

Zbinden, R. M., Thouret, V., Ricaud, P., Carminati, F., Cammas, J.P., and Nédélec, P.: Climatology of pure tropospheric profiles and column contents of ozone and carbon monoxide using MOZAIC in the mid-northern latitudes $\left(24^{\circ} \mathrm{N}\right.$ to $\left.50^{\circ} \mathrm{N}\right)$ from 1994 to 2009, Atmos. Chem. Phys., 13, 12363-12388, doi:10.5194/acp13-12363-2013, 2013.

Ziv, B., Saaroni, H., and Alpert, P.: The factors governing the summer regime of the Eastern Mediterranean, Int. J. Climatol., 24, 1859-1871, 2004. 